\title{
Light, temperature and sowing depth on germination of garden spurge
}

\section{Naira Moreli de Freitas $^{1}$ (i) Vanessa Francieli Vital Silva $^{1^{*}}$ (D) Celso Augusto Sato Teixeira ${ }^{1}$ (i) Luiz Augusto Inojosa Ferreira ${ }^{1}$ (D) Lucas Matheus Padovese ${ }^{1}$ (D) Rubem Silvério de Oliveira Jr$^{1}$ (D)}

${ }^{1}$ Programa de Pós-graduação em Agronomia, Departamento de Agronomia, Universidade Estadual de Maringá (UEM), 87020-900, Maringá, PR, Brasil. E-mail: vfvitalsilva@gmail.com. "Corresponding author.

ABSTRACT: Knowledge on weed biology and ecology is fundamental to provide suitable control practices in weed management systems. The objective of this research was to understand the effect of light and temperature on germination of Chamaesyce hirta, as well as to evaluate the effect of depth of seed placement in the soil in the emergence of the plant. Two experiments were conducted. In the first one, in the laboratory, the seeds were placed to germinate in plastic boxes and kept in a B.O.D. germination chamber, under constant temperatures of 20, 25, 30 and $35{ }^{\circ} \mathrm{C}$, either in the dark or under continuous light. Daily germination assessments were performed. The percentage of germinated seeds in the 10-day period and the germination speed index (GSI) were calculated. In the second trial, carried out in greenhouse conditions, 100 seeds were planted, under six levels of seeding depth $(0,1,2,3,4$ and $5 \mathrm{~cm})$ and three soil cover conditions: no straw, under black oats (Avena strigosa) straw and under corn (Zea mays) straw. Daily plant emergence was counted along 30 days and total emergence and GSI were calculated. Germination of $C$. hirta seeds occurs both in the presence and absence of light. For the highest temperature, both increased germination and GSI were reported in the presence of light. The highest levels of emergence were obtained with the absence of plant cover and under corn straw at $0 \mathrm{~cm}$ depth. The presence of black oat straw on the soil reduced the emergence of $C$. hirta.

Key words: Chamaesyce hirta, straw, abiotic factors, emergence, seeds.

Efeito da luz, temperatura e profundidade de semeadura na germinação de erva-de-santa-luzia

RESUMO: $O$ conhecimento a respeito da biologia e ecologia das plantas daninhas é fundamental para a adoção de práticas de controle adequadas dentro dos sistemas de manejo. O objetivo do trabalho foi avaliar o efeito da luz e da temperatura na germinação de Chamaesyce hirta, e o efeito de profundidade de semeadura na emergência das plantas, com a presença e ausência de cobertura vegetal no solo. Foram instalados dois experimentos. No primeiro, conduzido em laboratório, as sementes foram colocadas para germinar em caixas plásticas, do tipo "gerbox", e mantidas em câmara de germinação do tipo B.O.D., sob temperaturas constantes de $20,25,30$ e $35^{\circ} \mathrm{C}$ no escuro ou sob luz contínua. Foram realizadas avaliações diárias de germinação. Calculou-se a porcentagem total de sementes germinadas no período de 10 dias e o indice de velocidade de germinação (IVG). No segundo, conduzido em casa-de-vegetação, 100 sementes foram colocadas em vasos com solo, sob seis niveis de profundidade de semeadura $(0,1,2,3,4$ e $5 \mathrm{~cm}$ ) e três condições de cobertura do solo: sem palhada, com palha de aveia-preta (Avena strigosa) e com palha de milho (Zea mays). A emergência das plântulas foi registrada diariamente por um periodo de 30 dias, calculando-se a porcentagem total de emergência para cada tratamento e o índice de velocidade de emergência (IVE). A germinação das sementes de C. hirta ocorreu tanto na presença quanto na ausência de luz. Para a temperatura mais elevada houve maior porcentagem de germinação, bem como maior IVG, na presença de luz. Os maiores niveis de emergência ocorreram na ausência de cobertura vegetal e sob palhada de milho na profundidade de 0 $\mathrm{cm}$. A presença de palha de aveia-preta sobre o solo reduziu a emergência de C. hirta, mostrando-se como uma boa medida de controle cultural. Palavras-chave: Chamaesyce hirta, palhada, fatores abióticos, emergência, sementes.

\section{INTRODUCTION}

The lack of knowledge about the biology and ecology of weeds is one of the biggest limitations for the development of management strategies (YAMASHITA et al., 2008). The knowledge of aspects related to the germination of these plants, such as temperature, light, causes of dormancy and maximum depth that allows the emergence can be fundamental for the application of viable management systems.

The weed emergence flow is influenced by edaphoclimatic conditions, soil management and herbicide application, varying according to species, seed response patterns in relation to interference from environmental factors and cultural practices (ZANDONA et al., 2018). It can be said that soil temperature, light, water and air composition with oxygen and carbon dioxide are fundamental to the seed germination and seedling emergence processes (CALADO et al., 2011).

Germination is controlled by the interaction of environmental conditions and the physiological state of the seeds. Each plant species requires an ideal temperature for germination, and 
this temperature is considered optimal when it allows the greatest potential for germination in the shortest time. Light is also considered another important factor, since light intensity, wavelength and photoperiod can determine seed germination (CALADO et al., 2011).

The depth in the soil from which a seed is capable of germinating varies between species and is of ecological and agronomic importance (GUIMARÃES et al., 2002). Weed species that have few reserves usually germinate when placed at small depths in the soil, depending only on a light stimulus. With increasing depth and decreasing light, the germination process of these species can be inhibited. On the contrary, for weeds that do not require light, germination can occur even when the seeds are at greater depths (SAHA et al., 2019).

Regarding the garden spurge (Chamaesyce hirta), a plant native to Tropical America, little is known about the factors that affect seed germination and seedling emergence in the soil. This weed belongs to the Euphorbiacea family, it is an annual species of short cycle, with small inflorescences and great potential for seed production (SNELL \& BURCH, 1975, PINTO et al., 2014).

In addition to causing damage to crops by competition for water, light and nutrients, the garden spurge is host to some pests and phytopathogens in several crops and with wide distribution in agricultural areas.

In view of the above, this research studied the effect of light and temperature on the germination of Chamaesyce hirta, as well as to evaluate the effect of depth of seed placement in the soil in the emergence of the plant, in the presence and absence of vegetation cover.

\section{MATERIALS AND METHODS}

Two experiments were carried out with Chamaesyce hirta seeds from the capsules of adult plants collected in a high infestation site (seedlings with approximately 10 plants), in an area cultivated with pineapple, in the municipality of Santa Isabel do Ivaí, (PR), in October 2017.

\section{Experiment 1 - Effect of light and temperature on seed germination}

The seeds were placed to germinate on two sheets of Germitest paper, moistened with water, in the proportion of 2.5 times the dry paper mass. The seeds were subjected to four constant temperatures $\left(20,25,30\right.$ and $\left.35^{\circ} \mathrm{C}\right)$, in the absence and presence of light, in a completely randomized design, constituting a $4 \times 2$ factorial.

Each experimental unit consisted of a plastic "gerbox" box containing 50 seeds and for each treatment there were four replications. Then, the gerboxes were placed in B.O.D incubators and in germination chambers regulated to maintain a constant temperature of $20,25,30$ and $35 \pm 1{ }^{\circ} \mathrm{C}$, in the absence and presence of light.

The lighting condition was maintained in the germination chambers by using four light bulbs with a radiant flow density at the height of the boxes of $15 \mu \mathrm{mol} \mathrm{m} \mathrm{m}^{-2} \mathrm{~s}^{-1}$. In treatments with no light, the seeds were placed in black colored gerboxes, inhibiting the passage of light beams. The evaluations of treatments in dark conditions were carried out in a place lit only by green light.

Germination evaluations were performed daily for 10 days after installation of the tests. The seeds that showed root protrusion were considered as germinated. Variables analyzed were germination percentage (G) and germination speed index (GSI) as proposed by MAGUIRE (1962).

Germination $(\mathrm{G}):(\mathrm{N} / 50){ }^{*} 100$

$\mathrm{N}=$ number of germinated seeds for each gerbox

Germination speed index (GSI): G1 / N1 + G2 / N2 + ... $+\mathrm{Gn} / \mathrm{Nn}$, where:

$\mathrm{G}=$ number of normal seedlings computed in the counts; $\mathrm{N}=$ number of sowing days in the 1st, 2nd ... umpteenth assessment.

The germination and GSI data were subjected to analysis of variance, using the $\mathrm{F}$ test at $5 \%$ probability. The treatment means were compared using the Tukey test at $5 \%$ probability.

\section{Experiment 2 - Effect of sowing depth and soil cover on seedling emergence}

The research was carried out in a greenhouse in a randomized block design, with four replications. The treatments were organized in a $6 \times 3$ factorial scheme, considering six levels of sowing depth $(0,1,2,3,4$ and $5 \mathrm{~cm})$ and three conditions of soil cover, with two different stalks and one treatment without cover. The stalk used for ground cover was black oats (Avena strigosa) and corn (Zea mays) in an amount equivalent to a cover of $2.5 \mathrm{t} \mathrm{ha}^{-1}$ of dry matter.

One hundred seeds were placed per experimental unit (a $3 \mathrm{dm}^{3}$ pot). The soil used had a $\mathrm{CaCl}_{2} \mathrm{pH}$ of $4.9,3.42 \mathrm{cmolc}$ of $\mathrm{H}^{+}+\mathrm{Al}^{+3} \mathrm{dm}^{-3}$ of soil, $2.09 \mathrm{cmolc} \mathrm{dm}^{-3}$ of $\mathrm{Ca}^{+2}, 0.81 \mathrm{cmolc} \mathrm{dm}^{-3}$ of $\mathrm{Mg}^{+2}$, $0.31 \mathrm{cmolc} \mathrm{dm}^{-3}$ of $\mathrm{K}^{+} ; 8.70 \mathrm{mg} \mathrm{dm}^{-3}$ of P, $9.5 \mathrm{~g} \mathrm{dm}^{-3}$ of C; $84 \%$ sand; $2 \%$ silt and $14 \%$ clay. The pots were kept under daily irrigation. 
Seedling emergence was observed daily for a period of 30 days after sowing. In each evaluation, the emerged seedlings were removed from the pots so as not to interfere in subsequent emergencies. After the end of the evaluations, the total emergency percentage for treatments was calculated and the emergency speed index formula, proposed by MAGUIRE (1962), was used to calculate the emergency.

$\mathrm{ESI}=\mathrm{E} 1 / \mathrm{N} 1+\mathrm{E} 2 / \mathrm{N} 2+\ldots \mathrm{En} / \mathrm{Nn}$

$\mathrm{ESI}=$ emergency speed index;

$\mathrm{E}=$ number of normal seedlings computed in the counts; and

$\mathrm{N}=$ number of days of sowing in the first, second and umpteenth evaluation.

The data obtained were subjected to analysis of variance, using the $F$ test at $5 \%$ probability. The treatment means were compared using the Tukey test at $5 \%$ probability.

\section{RESULTS AND DISCUSSION}

\section{Experiment 1 - Effect of light and temperature on seed germination}

The germination of $C$. hirta seeds occurred both in the presence and absence of light (Figure 1) and was observed from the second day, for treatments at a temperature of $35^{\circ} \mathrm{C}$. At temperatures of 25 and $30{ }^{\circ} \mathrm{C}$, the germination started from the third day; however, at a temperature of $20^{\circ} \mathrm{C}$, the germination was observed only after the eighth day of evaluation.

The germination percentage of $C$. hirta seeds are shown in table 1 . The highest percentages of $C$. hirta germination were observed for seeds placed at $35^{\circ} \mathrm{C}$, both in the presence and absence of light. The values observed at the other temperatures in the two lighting conditions did not differ. The change in absorbance of the wavelength of the red to distant red spectrum during photoreversibility elucidates the seedling germination in the dark (BUTLER et al., 1959), which may explain the possibility of this weed in germinating under the two lighting conditions.

The only significant difference for the light factor was observed at a temperature of 30 ${ }^{\circ} \mathrm{C}$. In this condition, the seeds of $C$. hirta showed a higher percentage of germination in the presence of light. For other temperatures, the presence or absence of lighting did not interfere with the germination process. Although, only the temperature of $30^{\circ} \mathrm{C}$ has shown a significant difference regarding the presence of light, it is interesting to note that at the three highest temperatures, germination is higher than the value observed in the absence of light. SAHA et al. (2019) stated that C. hirta is a tropical species and requires light and high temperatures for germination, which explains the results of germination reported at the highest temperature evaluated in this experiment.

Higher values of GSI were also observed at the highest temperature in the presence and absence of light (Table 2). This factor indicated that, in warmer regions, in addition to the higher germination percentage, the seeds become seedlings faster, which increases the competitive capacity of C. hirta. SANTOS et al. (2016) observed that in places of lower altitude; and consequently, of higher temperature, there is a higher occurrence of $C$. hirta

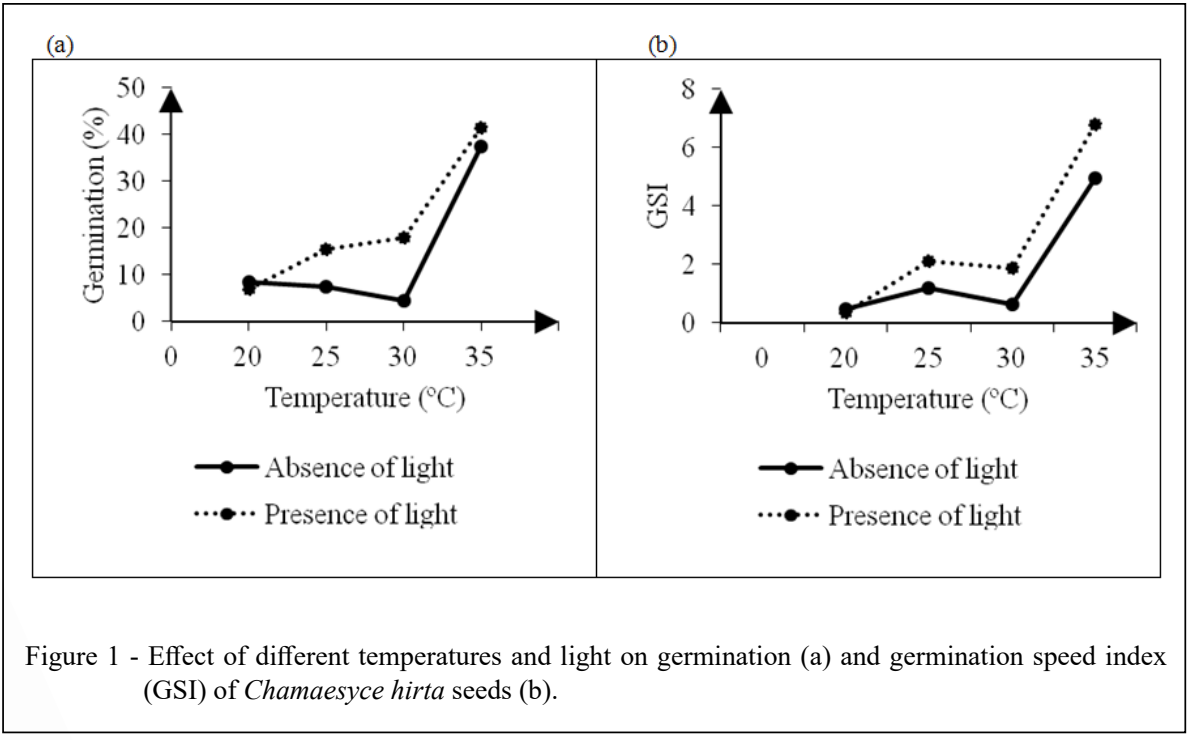

Ciência Rural, v.51, n.10, 2021. 
Table 1 - Germination percentage of Chamaesyce hirta seeds when subjected to different temperatures and lighting conditions for a period of 10 days.

\begin{tabular}{lccc}
\hline & & & \\
\hline
\end{tabular}

Averages followed by the same letter do not differ significantly from each other, uppercase in the column and lowercase in the line, by the Tukey test, at $5 \%$ probability.

when compared to places of higher altitude and milder temperature.

At temperatures of 20,25 and $30{ }^{\circ} \mathrm{C}$ there was no significant difference in GSI for the presence or absence of light; however, at $35^{\circ} \mathrm{C}$ the GSI found for seeds germinated in the presence of light was higher than the GSI of seeds germinated in the dark. This indicated that at high temperatures, where the germination flow is more intense, the presence of light factor also contributed to the increase in germination speed.

When evaluating the germination of the garden spurge in four light conditions (white light, red light, extreme red light and dark), FERREIRA et al. (2017) also observed that this species is indifferent to light, germinating in all light conditions. These authors also highlighted the high value of GSI reported, associating this result to the small size of the seeds.
Experiment 2 - Effect of sowing depth and soil cover on seedling emergence

Regardless of the vegetation cover, the sowing depth of $0 \mathrm{~cm}$ showed the highest levels of emergence in relation to the other depths (Figure 2).

There was a significant interaction for the sowing depth and vegetation cover factors in the emergence of $C$. hirta seeds in the evaluations carried out in the period of 30 days after sowing (DAS) (Table 3). For the three soil cover conditions, the greatest emergence was observed for seeds placed on the soil surface $(0 \mathrm{~cm})$. The emergence decreases significantly for greater depths, with no differences between 1 to $5 \mathrm{~cm}$ when the soil was covered or between 1 to $4 \mathrm{~cm}$ when the soil was uncovered. The reduction in the emergence of $C$. hirta seeds positioned from a depth of $1 \mathrm{~cm}$ may have occurred due to the difficulty of radicle and hypocotyl emission caused by the deposition of soil above the seed, since

Table 2 - Germination speed index (GSI) of Chamaesyce hirta seeds when subjected to different temperatures and light conditions for a period of 10 days.

\begin{tabular}{lccc}
\hline & & & \\
& & & \\
& & & \\
\hline
\end{tabular}

Averages followed by the same letter do not differ significantly from each other, uppercase in the column and lowercase in the line, by the Tukey test, at $5 \%$ probability.

Ciência Rural, v.51, n.10, 2021. 


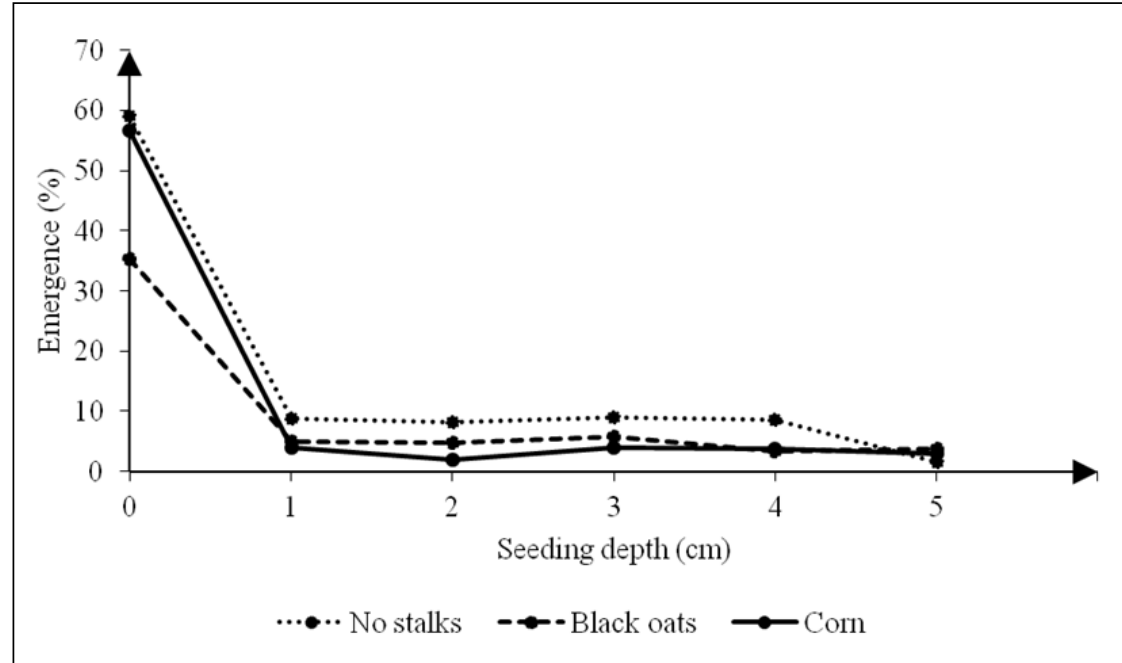

Figure 2 - Emergence of Chamaesyce hirta under different sowing depths and vegetation cover.

the absence of light does not inhibit the germination of this seed species.

When analyzing the phytosociology of spontaneous plants in three coffee growing systems with tree legumes in different shading systems, COELHO et al. (2004) collected soil at depths 0 to $5 \mathrm{~cm}$ and 15 to $20 \mathrm{~cm}$ and their phytosociology was monitored in a greenhouse, during the period of nine months. The garden spurge was reported only at a depth of 0 to $5 \mathrm{~cm}$. This fact showed not only the germination of this species at small depths, but also the survival of the seeds in the soil seed bank at lower depths.
The emergence of seeds can be influenced by the depth in which they are in the soil. CANOSSA et al. (2007) observed that the emergence of seedlings of Alternanthera tenella, in the period of 28 days after sowing, was influenced by the depth of the soil, both in the absence of straw and in the presence of black oat straw, reducing to 4 and $5 \mathrm{~cm}$ of depth, and without emergence at $10 \mathrm{~cm}$. In relation to $C$. hirta, the fact that the seeds are very small may have hindered the emergence even at small depths.

The effect of straw cover was observed only at depths of 0 and $2 \mathrm{~cm}$. For seeds positioned on the soil surface $(0 \mathrm{~cm})$, the absence of straw

Table 3 - Percentage of Chamaesyce hirta emergence under different sowing depths and vegetation cover after 30 days of sowing.

\begin{tabular}{lccccc}
\hline & & & & & \\
& & & & \\
\end{tabular}

Averages followed by the same letter do not differ significantly from each other, uppercase in the column and lowercase in the line, by the Tukey test, at $5 \%$ probability.

Ciência Rural, v.51, n.10, 2021. 
and the presence of corn straw on the soil surface present higher percentages of emergence in relation to black oat straw. However, for seeds positioned at $2 \mathrm{~cm}$ depth, the absence of straw provided greater emergence when compared to corn straw.

A similar result was observed by FERREIRA et al. (2017) when evaluating the influence of six levels of sugarcane straw $(0,5,10$, 15,20 and $25 \mathrm{t} \mathrm{ha}^{-1}$ ) on seeds of garden spurge. In this case, the increase in the level of straw over the soil negatively interfered in the emergence of the species, and the presence of $5 \mathrm{t} \mathrm{ha}^{-1}$ reduced the emergence to less than $30 \%$ in relation to level 0 and there was no emergence of seedlings in the levels 15 and $25 \mathrm{t} \mathrm{ha}^{-1}$. Results obtained were attributed to the physical effect of mulch, since the authors also concluded that the luminosity has little influence on seed germination.

The lower emergence of $C$. hirta under black oat straw may be related to the allelopathic effect of this species in suppressing the seedling germination of some weeds. HAGEMANN et al. (2010) evaluated the allelopathic effect of aqueous extracts from five black oat cultivars registered for cultivation in Brazil. It was concluded that there was inhibition in the germination and development of Italian ryegrass (Lolium multiflorum Lam.) and fireplant (Euphorbia heterophylla L.) seedlings in the germination percentage, root length and hypocotyl evaluations, at 14 days after the experiment installation due to the black oat allelopathic potential.
The variable emergence speed index (ESI) showed a similar behavior to the emergence, with higher values for the sowing depth of $0 \mathrm{~cm}$ and decrease for the other depths (Figure 3). The effect of sowing depth was also observed for ESI. The depth of $0 \mathrm{~cm}$ showed the highest indexes in all straw conditions (Table 4). At this sowing depth, a higher ESI was observed for the treatment without cover, which indicated that the emergence of $C$. hirta seedlings is faster when there is no coverage in the soil. For the other depths evaluated, there was no significant difference between the coverages evaluated.

Results confirmed that there is an effect of sowing depth in the emergence of $C$. hirta, since from a depth greater than $1 \mathrm{~cm}$, there is a decrease in emergence, as well as a decrease in the speed at which seedlings emerge.

\section{CONCLUSION}

Higher temperatures $\left(35^{\circ} \mathrm{C}\right)$ intensify the germination flow and, in the presence of light, they also collaborate to increase the germination speed of garden spurge. Corn straw on the soil does not interfere with the emergence of $C$. hirta; however, when it was present, it reduced the emergence speed, which may affect the competitive potential of this species. Conversely, the presence of black oat straw on the soil surface suppresses the emergence of $C$. hirta, appearing to be a good measure of cultural control.

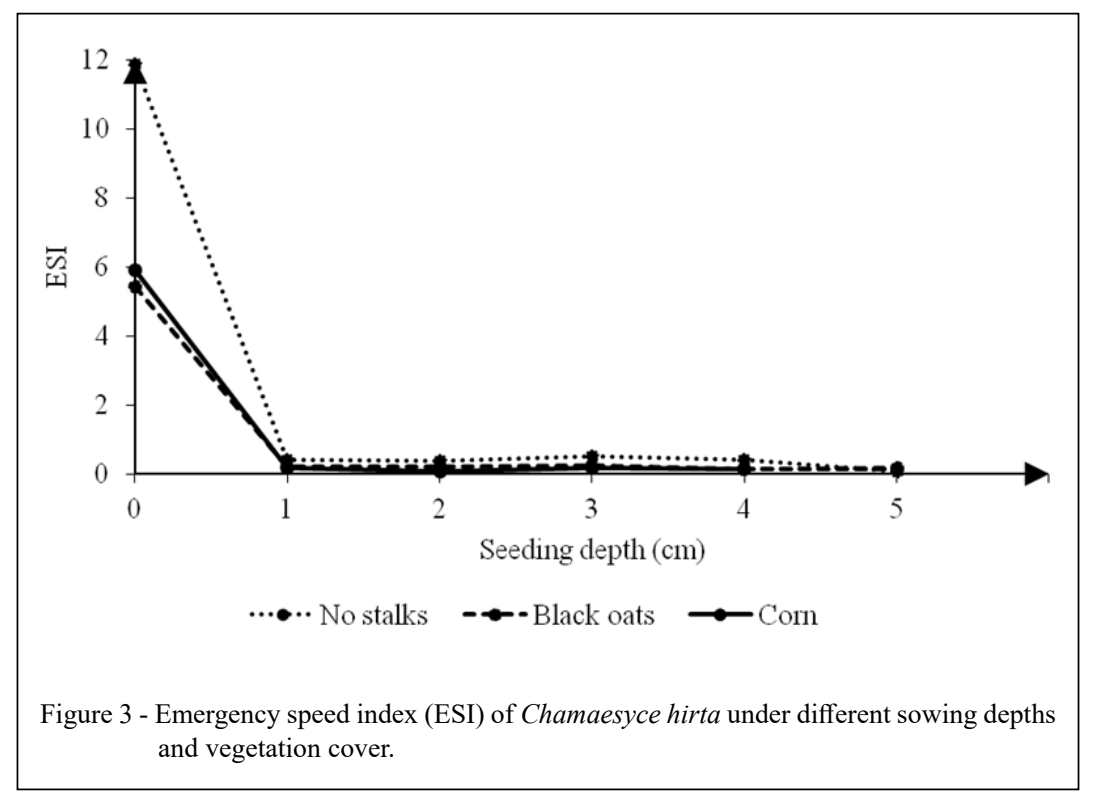

Ciência Rural, v.51, n.10, 2021. 
Table 4 - Chamaesyce hirta emergence speed index (ESI) under different sowing depths and soil cover after 30 days of sowing.

\begin{tabular}{|c|c|c|c|c|c|c|}
\hline Seeding depth & \multicolumn{2}{|c|}{---------------No stalks-------------- } & \multicolumn{2}{|c|}{----------Black oats------------ } & \multicolumn{2}{|c|}{-----------------Corn------------------ } \\
\hline $0 \mathrm{~cm}$ & 11.88 & $\mathrm{Aa}$ & 5.44 & $\mathrm{Ab}$ & 5.89 & $\mathrm{Ab}$ \\
\hline $1 \mathrm{~cm}$ & 0.41 & $\mathrm{Ba}$ & 0.22 & $\mathrm{Ba}$ & 0.18 & $\mathrm{Ba}$ \\
\hline $2 \mathrm{~cm}$ & 0.38 & $\mathrm{Ba}$ & 0.22 & $\mathrm{Ba}$ & 0.09 & $\mathrm{Ba}$ \\
\hline $3 \mathrm{~cm}$ & 0.52 & $\mathrm{Ba}$ & 0.26 & $\mathrm{Ba}$ & 0.18 & $\mathrm{Ba}$ \\
\hline $4 \mathrm{~cm}$ & 0.40 & $\mathrm{Ba}$ & 0.14 & $\mathrm{Ba}$ & 0.16 & $\mathrm{Ba}$ \\
\hline $5 \mathrm{~cm}$ & 0.07 & $\mathrm{Ba}$ & 0.18 & $\mathrm{Ba}$ & 0.15 & $\mathrm{Ba}$ \\
\hline F (interaction) & \multicolumn{6}{|c|}{ 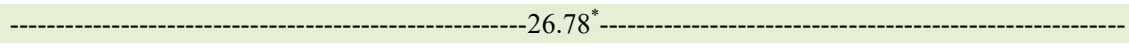 } \\
\hline $\mathrm{CV}(\%)$ & ------------ & ---------. & & ------------ & & \\
\hline
\end{tabular}

Averages followed by the same letter do not differ significantly from each other, uppercase in the column and lowercase in the line, by the Tukey test, at $5 \%$ probability.

\section{ACKNOWLEDGEMENT}

Coordenação de Aperfeiçoamento de Pessoal de Nível Superior (CAPES) provided scholarships to the authors.

\section{DECLARATION OF CONFLICT OF INTEREST}

We declare no conflict of interest and emphasize this manuscript are submitting exclusively in Ciência Rural.

\section{AUTHORS' CONTRIBUTIONS}

We declare that all authors have contributed for manuscript execution and agree with terms and conditions of Ciência Rural.

\section{REFERENCES}

BUTLER, W. L. et al. Detection, assay and preliminary purification of the pigment controlling photosensitive development of plants. Proceedings of the National Academy of Sciences, v.45, n.12, p.1703-1708, 1959. Available from: <https://www.pnas.org/ content/45/12/1703>. Accessed: Jan. 10, 2019. doi: 10.1073/ pnas.45.12.1703.

CALADO, J. M. G. et al. Weed emergence in autumn under temperate conditions. Planta Daninha, v.29, n.2, p.343-349, 2011. Available from: $<$ https://www.scielo.br/scielo.php?pid=S010083582011000200012\&script $=$ sci_arttext $>$. Accessed: Dec. 19, 2018. doi: 10.1590/ S0100-83582011000200012.

CANOSSA, R. S. et al. Sowing depth affecting Alternanthera tenella seedlings emergence. Planta Daninha, v.25, n.4, p.719-725, 2007 Available from: <https://www.scielo.br/scielo.php?pid=S010083582007000400008\&script=sci_arttext $>$. Accessed: Dec. 19, 2018. doi: 10.1590/S0100-83582007000400008.

COELHO, R. A. et al. Influence of shade on spontaneous plant population in crop area of coffee (Coffea canephora) under organic management. Agronomia, v.38, n.2, p.23-28, 2004. Available from: <http://www.ia.ufrrj.br/revista/volume382.htm>. Accessed: Jan. 25, 2019

FERREIRA, D. T. R. G. et al. Germination in three Euphorbiaceae influenced by light and levels of straw. Revista Agro@mbiente, v.11, n.3, p.215-222, 2017. Available from: <https://revista.ufrr.br/ agroambiente/article/view/3852>. Accessed: Feb. 08, 2019. doi: 10.18227/1982-8470ragro.v11i3.3852.

GUIMARÃES, S. C. et al. Tridax procumbens emergence as a function of sowing depth, substrate clay content and light incidence. Planta Daninha, v.20, n.3, p.413-419, 2002. Available from: $<$ https://www.scielo.br/scielo.php?script=sci arttext\&pid=S0100$83582002000300012 \& \operatorname{lng}=\mathrm{en} \& \mathrm{nrm}=\mathrm{iso} \& \mathrm{t} \operatorname{lng}=\mathrm{pt}>$. Accessed: Jan. 25, 2019. doi: 10.1590/S0100-83582002000300012.

HAGEMANN, T. R. et al. Effect of extracts from the aboveground part of oat genotypes on ryegrass and wild poinsettia. Bragantia, v.69, n.3, p.509-518, 2010. Available from: <https:// www.scielo.br/scielo.php?script $=$ sci arttext\&pid $=S 0006$ 87052010000300001\&lng=es\&nrm=iso $>$. Accessed: Feb. 08, 2019. doi: 10.1590/S0006-87052010000300001.

MAGUIRE, J. D. Speed of germination-aid in selection and evaluation for seedling emergence and vigor. Crop Science, v.2, n.1, p.176-177, 1962. Available from: <https://doi.org/10.2135/cr opsci1962.0011183X000200020033x>. Accessed: Nov. 12, 2018. doi: 10.2135/cropsci1962.0011183X000200020033.

PINTO, M. V. et al. Botanical, phytochemical and physicochemical study of Euphorbia hirta L. (Euphorbiaceae). Revista Brasileira de Plantas Medicinais, v.16, n.3, p.649-656, 2014. Available from: $<$ https://www.scielo.br/scielo.php?script $=$ sci abstract\&pid=S1516-05722014 000700003\&lng=en\&nrm=iso $>$. Accessed: Dec. 19, 2018. doi: 10.1590/1983-084x/09_204.

SAHA, D. et al. Emergence of garden spurge (Euphorbia hirta) and large crabgrass (Digitaria sanguinalis) in response to different physical properties and depths of common mulch materials. Weed Technology, v.34, n.2, p.172-179, 2019. Available from: $<$ https://www.cambridge.org/core/journals/weed-technology/ article/emergence-of-garden-spurge-euphorbia-hirt a-an d-largecrabgrass-digitaria-sanguinalis-in-response-to-different-physicalproperties-and-depths-of-common-mulch-materials/FF083B7C 
0C701500DDF8665837814D2F>. Accessed: Jun. 29, 2020. doi: 10.1017/wet.2019.88.

SANTOS, W. F. et al. Factors associated with weed occurrence in Southwest region of Goiás. African Journal of Agricultural Research, v.11, n.52, p.5178-5191, 2016. Available from: <https:// academicjournals.org/journal/AJAR/article-full-text/B43F52062219>. Accessed: Jan. 13, 2019. doi: 10.5897/AJAR2016.11939.

SNELL, T. W.; BURCH, D. G. The effects of density on resource partitioning in Chamaesyce hirta (Euphorbiaceae). Ecology, v.56, n.3, p.742-746, 1975. Available from: $<$ https://esajour nals. onlinelibrary.wiley.com/doi/abs/10.2307/1935512>. Accessed: Dec. 19, 2018. doi: 10.23 07/1935512.
YAMASHITA, O. M. et al. The influence of temperature and light on Porophyllum ruderale (Jacq.) Cass. seed germination. Revista Brasileira de Sementes, v.30, n.3, p.202-206, 2008. Available from: <https://www.scielo.br/ scielo.php?pid=S0101-31222008000300027\&script $=$ sci abstract\&tlng $=p t>$. Accessed: Jan. 13, 2019. doi: 10.1590/S010131222008000300027.

ZANDONA, R. R. et al. Mathematical modeling of the drought emergency flow: crop management decision tool. Revista Brasileira de Herbicidas, v.17, n.1, p.3-11, 2018. Available from: <http://www.rbherbicidas.com.br/index.php/rbh/article/ view/538>. Accessed: Jan. 13, 2019. doi: 10.7824/rbh. v17i1.538. 